\title{
ENGINEERING, THE ENVIRONMENT AND SUSTAINABILITY Mind Expanding and Necessary
}

\author{
Domenico Grasso \\ Picker Engineering Program \\ Smith College \\ Northampton, MA 01062
}

\begin{abstract}
We travel together, passengers on a little spaceship, dependent on its vulnerable reserves of air and soil; all committed to our safety, to its security and peace; preserved from annihilation only by the care, the work; and I will say the love, we give our fragile craft.

We cannot maintain it half fortunate, half miserable, half confident, half despairing, half slaves to ancient enemies of humanity, half free in a liberation of resources undreamed of until this day.
\end{abstract}

No craft, no crew, can travel safely, with such vast contradictions. On their resolution depends the survival of us all.

Adlai Stevenson

1965, delivered before the United Nations Economic and Social Council.

\section{INTRODUCTION}

The earth is 4.5 billion years old. Life started on this planet about 3.5 billion years ago. Multi-celled organisms were active in the oceans about 500 million years ago. Since that time there have been 5 mass extinctions on the planet. Homo sapiens are thought to have first arrived on the earth about 500,000 years ago. Our wisdom, at least the wisdom that we think differentiates us from other primates such as chimpanzees can been attributed to only a $1.6 \%$ difference in our gene pools. Although $1.6 \%$ may not sound like a lot, it is enough to account for the Mona Lisa, the Brandenburg concertos, and the industrial revolution. There are few that would argue that human ingenuity has not improved our quality of life, including both its purely aesthetic and the more intimately pragmatic aspects. However, this $1.6 \%$ difference in gene pool can also be credited with 
- bioconcentration of anthropogenic hydrophobic contaminants in virtually every living creature's adipose tissue,

- a net annual input of 3.5 gigatons of $\mathrm{CO}_{2}$ to the atmosphere,

- an annual socio-industrial materials usage rate that returns between $1 / 2$ and $3 / 4$ of industrial inputs back to the environment as waste, and

- a daily energy usage rate that ranges from approximately $2000 \mathrm{cal} /$ day for hunter/gather societies to a global average of $30,000 \mathrm{cal} /$ day to an U.S. average of $180,000 \mathrm{cal} /$ day.

Indeed, if we were to compress the history of the planet into a 24 hour day, then the time that it has taken humanity to significantly deplete resources, threaten biodiversity and contaminate the environment could be squeezed into the last 4 milliseconds of the day.

"To overcome today's environmental problems we will need both understanding and moral fortitude to compensate for our genetically endowed predilection for short-term gain" . The understanding that is needed is in part technological, in part economic, and in part an understanding of the human condition. Engineers must play a pivotal role in the solution of these problems - just as they did in their creation. However, for engineers to play this role, a major paradigm shift is needed. In the words of Albert Einstein, "The world we have created has problems that cannot be solved thinking the way we used to think when we created them". Unfortunately, notwithstanding new ABET criteria, engineering programs rarely, if ever, require a course devoted entirely to the complexity of environmental consequences accompanying engineering decisions. It is true that general civil engineering curricula commonly require a course in environmental engineering. However, this course often centers on purely technical aspects of the treatment of water and wastewater with an occasionally diversion into air quality. Although sustainability has become a fashionable buzzword and many engineering programs are eager to attract research funds to address issues associated with green manufacturing, industrial ecology, etc., few programs have found it necessary to educate the undergraduate engineers who will comprise the majority of the future workforce in these pressing topics. Society can ill-afford engineers that have not been properly prepared to directly engage in the debates that form the basis for decisions with environmental consequences.

Smith College, the only women's college and one of the few liberal arts colleges with an engineering program, requires all engineering majors to take a course entitled Engineering, the Environment and Sustainability. Students learn fundamental principles that govern decisions with environmental consequences. Students are able to incorporate that understanding in constructing engineering solutions that are protective of human health and natural resources. Unlike typical required environmental courses offered as part of traditional civil engineering curricula, the Smith course is divided into three major parts: social balances, physical balances (mass and energy), and economic balances. Balances are used to underscore the concept of tradeoff and that there are no unequivocal answers. The Smith course is purposefully designed to be taken early in the student 
academic plan of study (first or second year) so as to provide a filter through which subsequent courses may be viewed.

\section{Course Prologue}

As their first assignment, each student is asked to calculate her ecological footprint, the biologically productive area needed to produce resources and absorb generated waste to maintain her lifestyle (Leadership in Environment and Development http://www.lead.org/leadnet/footprint/default.htm). Students are often surprised to discover how excessive their burden on the planet is, even for the most modest lifestyles.

Our first reading, "A Special Moment in History" ii provides a perspective on both the earth's and humanity's history and their interrelationship. The second reading "Back From Chaos" "iii, is an excerpt from E.O. Wilson's recent book, Consilience, where he argues for a unity of knowledge among enlightened thinkers. Finally, students are also asked to read the United Nations Industrial Development Organization position paper on sustainable development (http://www.unido.org/doc/50356.htmls). The UNIDO paper outlines what sustainable development has come to mean to analysts, decision-makers and the public at large, sketches an approach to the measurement and monitoring of sustainable development, reassesses industrial development in light of sustainability, and describes the role of capacity building for sustainable industrial development. We then discuss whether we are at a special point in the history of the planet and/or whether we are at a special point in the history of humanity. Are they different? What is the role of the engineer in the past? What will be the role of the engineer in the future? How should engineers be educated to, in the words of Dartmouth Engineering Dean Lewis, engage in the great debates that define our times?

This sets the stage for the importance of well-educated and thoughtful engineers as leaders of society and hopefully underscores the importance of the course within the framework of their education.

\section{SOCIAL BALANCES}

The course then turns to a discussion of social balances. How does society in general address and mediate such issues as risk estimation, risk assignment/acceptance, environmental justice, the precautionary principle, and sustainable development. What motivates decision making with environmental consequences? Special attention is given to the disparity between developed and developing countries. Students gain an appreciation for the tension between technological development and environmental protection.

As a personal exercise in perceived and acceptable risk, students learn about the quality of bottled water by reading "Bottled Water: Pure Drink or Pure Hype?"

(http://www.nrdc.org/water/drinking/bw/bwinx.asp) and research the quality of their hometown water quality by using Environmental Defense's Scorecard (http://scorecard.org/) and other 
information (many students contact their hometown water treatment plan to get water analyses). They then write a short paper entitled

THE VALUE OF BOTTLED WATER TO ME, IN MY HOMETOWN COMMUNITY

To gain a perspective regarding motivations in resource utilization and environmental decision making, the students then read "The Tragedy of the Commons",iv "Can Selfishness Save the Environment?", , and write a paper on the following topic

IN A WORLD OF DISPARATE COMMONS, WHAT IS THE RESPONSIBILITY OF DEVELOPED NATIONS TO UNDERDEVELOPED NATIONS?

This assignment gives students time to explore motivations, responsibility, risk assignment, and equity on global scale and again underscores the role of technology in human welfare.

\section{Physical Balances}

The second part of the course focuses on what might be considered the basis of traditional environmental engineering courses - construction of elementary mass and energy balances. Engineers must, as a necessary but not sufficient requirement of their profession, be facile with the transformation of physical circumstances into mathematical metaphors. The global consequences of mass and energy conservation, although simple in theory, seem to have eluded many myopic decision-makers, who define boundaries to suit their needs without regard to external factors. Indeed, it is only fairly recently that the concepts and implications of industrial ecology and full life cycle analysis have been considered in engineering decisions.

This section of the course begins with simple non-reactive mass balance examples, such as calculating the concentration at the confluence of different streams, which then lead into more complicated reactor modeling examples. The primary objective of this portion of the course is developing in the students a quantitative understanding of the concepts of mass and energy balance. After many homework assignments, these concepts are then applied to an elementary semester-long project on calculating the quantity of waste a receiving stream can assimilate from the expansion of an industrial facility (see Box 1 below)

\section{Box 1. Physical Balance Semester Team Project}

An industrial development located in Northampton is proposing to discharge a wastewater into a local river, which has a 7Q10 of $0.3 \mathrm{cms}$. They estimate a discharge rate of $0.1 \mathrm{cms}$ with a $\mathrm{BOD}_{5}$ of $175 \mathrm{mg} / \mathrm{L}$, a DO concentration of $2 \mathrm{mg} / \mathrm{l}$, a deoxygenation rate constant of $0.19 \mathrm{~d}^{-1}$ at $20^{\circ} \mathrm{C}$ (temperature coefficient, $\theta$, of 1.056) and a water temperature of $25^{\circ} \mathrm{C}$. To what level should the wastewater be treated to ensure that Commonwealth of Massachusetts Water Quality Standards (314 CMR 4.00, see 
www.state.ma.us/dep/) are not exceeded? Solve using the Streeter-Phelps method and, at a minimum, graphically depict the oxygen-sag curve, deficit profile and, on a separate graph, $\mathrm{BOD}_{5}$ concentration. For modeling purposes, assume the river geometry downstream of the discharge can be represented as shown in the schematic. Water quality above the proposed discharge location consists of negligible $\mathrm{BOD}_{5}$, a $\mathrm{DO}$ concentration of $7.5 \mathrm{mg} / \mathrm{L}$ and a temperature of $25^{\circ} \mathrm{C}$.

Conduct a sensitivity analysis on $\mathrm{k}_{\mathrm{d}}$ and both $\mathrm{k}_{\mathrm{r}}$ 's by varying each (individually) one order of magnitude in each direction.

Comment and interpret all of your results as if you were presenting the information to a client. Submit a professionally structured and written report.

Although this a traditional upper level environmental engineering project, it teaches basic concepts of model building, including calibration, validation, and sensitivity analyses that are broadly applicable to many other environmental scenarios such as global warming or acid rain.

The same mass balance approaches are used to explore issues of resource extraction/utilization and population growth. Students also gain exposure to key elements regarding industrial ecology and life cycle analysis through various readings and a project on the economic input-output life cycle analysis of automobiles using the Carnegie-Mellon University Green Design Initiative web site http://www.eiolca.net/. The areas of water and air treatment are reviewed but not in as much depth as a traditional introductory environmental course in a typical civil engineering program.

\section{ECONOMIC BALANCES}

Technology alone rarely drives governmental or corporate environmental policy decisions. As a key to a more sustainable development the use of economic instruments for environmental policy has been on the agenda for many years. Economic instruments have often been applied on the basis of the principle of the least political resistance. It is only prudent to devote a significant portion of the course to a consideration of the role of economics in environmental decision making.

Students learn about the time - value of money, cost-benefit analysis, how markets work, why the environment is a classic market failure, and how to address environmental externalities with various instruments such as taxes and tradable permits. An in class tradable permits exercise (developed by Professor R. Stavins at Harvard University's Kennedy School of Government) is conducted to illustrate the advantages of this system (see Box 2 below). 


\section{Box 2. Tradable Permit Exercise}

Your industry produces widgets using a variety of inputs. One of the essential inputs in production of widgets is ecotox, some of which is released into the air during production. Ecotox is a pollutant with no local health effects, but if released into the atmosphere contributes to regional haze. The State has decided that ecotox releases need to be regulated. Because ecotox is a uniformly mixed pollutant, reductions of ecotox anywhere in the airshed have the same effect on overall environmental quality in the area. There are three other firms in the airshed that also release ecotox. Current overall releases of ecotox from these four firms is 50 tons per year. The State has decided to reduce ecotox pollution by 30 tons per year. This represents a 60 percent reduction over the baseline level of 50 tons per year.

The Commonwealth of Massachusetts has hired Smith Associates to advise them in their regulatory design. Smith Associates determined that there was a lot of heterogeneity in abatement costs across the four ecotox releasing firms in the airshed. Using this knowledge, and combined with the knowledge that ecotox is a uniformly mixed pollutant, the Commonwealth decided to use a cap-and-trade system for ecotox reductions. Each firm will be issued permits denominated in tons, with each firm receiving an initial allocation of 5 permits each. Your engineers have estimated for you the marginal cost of reducing ecotox releases at your facility. This marginal cost schedule is provided on the next page.

Please look over the marginal cost curve and discuss the following questions with your group:

1. How many units of ecotox do you release in the baseline scenario. Hint: Your engineers gave you estimates of the marginal cost of reducing only units of pollution that you actually generated in the baseline.

2. If you only have permits to cover 5 tons of pollution, how many units will you have to abate assuming that you engage in no trade?

3. What is your total abatement cost without trade (assume no fixed costs)?

4. What is your marginal cost of the last unit of ecotox that you abate without trade?

5. What is the marginal cost of the next unit of ecotox that you could abate, thereby allowing you to sell a permit?

6. Using your answers to questions 4 and 5, at what price would you buy a permit? At what price would you sell a permit? Think about at what price you would sell two permits? Buy two permits? Three? Etc.

Finally, to illustrate the tension between technological and economic issues associated with the solution to environmental problems, students are asked to read the controversial papers "The Value of the World's Ecosystem"vi "No Middle Way on the Environment" vii , and "Can Pollution Problems be Effectively Solved by Environmental 
Science and Technology?" viii. While much in-class discussion ensues, students are also asked to reflect on their readings and write a paper on one of the two following topics

IF HUMANITY IS TO SUCCESSFULLY BALANCE ITS NEEDS AND RESOURCES ENSURING A SUSTAINABLE SOCIETY, WHAT WILL BE THE ROLE OF SCIENCE AND ENGINEERING?

OR

IS THE STRUCTURING AND IMPLEMENTATION OF SELF-SERVING ECONOMIC INCENTIVES THE ONLY (INTER ALIA ACCEPTABLE, EFFICIENT, EQUITABLE) WAY TO INSURE ENVIRONMENTAL QUALITY?

\section{SUMMARY}

The engineering program at Smith hopes to embody the sentiments so eloquently described by Thomas Henry Huxley more then a century ago

Education is the instruction of the intellect in the laws of nature, under which name I include not merely things and their forces but men [sic] and their ways, and a fashioning of the affections and of the will into and earnest and loving desire to move in harmony with these laws."

To sustain human civilization into the foreseeable future we must begin by educating the engineering leaders of tomorrow to consider the full consequences of their actions. We in the academy must take a more global approach to contectualizing the myriad of environmental issues into undergraduate engineeirng curricula. The Smith course, "Engineering, the Environment, and Sustainability" is a first step in this direction. Clearly, there is not enough time in one semester to address all the important issues. However, providing the intellectual scaffolding and encouraging students to stand away from the canvas and see the entire painting is a beginning. There are no correct algorithms to be employed in preparing for the future, only reflective well-informed and reasoned thought. The course ends hopefully leaving students not with a lugubrious sense of the enormity of the issues we face as a contemporary society, but with an optimistic understanding that they may become the well educated engineers that will think broadly, bridge many disciplines, and lead our society to a sustainable and equitable future.

References

${ }^{\mathrm{i}}$ McMichael, A., Planetary Overload, 1993.

${ }^{\text {ii }}$ McKibben, B., “A Special Moment in History”, The Atlantic Monthly, 281 (5): 55 - 78,1998.

iii Wilson, E.O., "Back From Chaos", The Atlantic Monthly, 281 (3): 41 - 62, 1998. 
${ }^{\text {iv }}$ Hardin, G., "The Tragedy of the Commons,", Science, 162:1243-1248, 1968.

v Ridley, M., Low, B.S., “Can Selfishness Save the Environment?”, The Atlantic Monthly, 272, (3): 76-86, 1993.

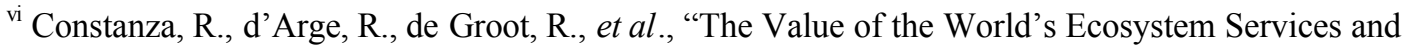
Natural Capital”, Nature, 387: 253-261, 1997.

vii Ehrlich, P.R., Daily, G.C., Daily, S.C., "No Middle Way on the Environment" The Atlantic Monthly, 280 (6): 98 - 104, 1997.

viii Huesemann, M, "Can Pollution Problems be Effectively Solved by Environmental Science and Technology?", Ecological Economics, 37: 271-287, 2001. 